\title{
Hepatosellüler karsinomada spontan intraperitoneal hemorajik rüptür: Olgu sunumu
}

\section{Spontaneous intraperitoneal hemorrhagic rupture of hepatocellular carcinoma: A case report}

\author{
Murat Ulaş, İlter Özer, Volkan Öter*, Erol Aksoy, Şükran Ziyşan Sakaoğulları, \\ Erdal Birol Bostancı
}

Gastroenteroloji Cerrahisi Kliniği (Doç. Dr. M. Ulaş, Doç. Dr. İ. Özer, Dr. V. Öter, Dr. E. Aksoy, Prof. Dr. E. B. Bostanc1), Patoloji Kliniği (Ş. Z. Sakaoğulları), Türkiye Yüksek İhtisas Eğitim ve Araştırma Hastanesi, TR-06640 Ankara

\section{Özet}

Hepatosellüler karsinomun (HSK) intraperitoneal hemorajik rüptürü, ölümle seyredebilen bir komplikasyondur. Seçilmiş vakalarda ana tedavi seçenekleri cerrahi girişim ve arteriel embolizasyondur. $\mathrm{Bu}$ yazıda hepatosellüler karsinomun spontan rüptürü sonrası gelişen intraperitoneal kanamalı olgu sunulmuştur. Karın ağrısı ve hemorajik şok tablosunda dış merkezde acile başvurmuş 70 yaşında bir erkek hastadır. Karaciğerde intraperitoneal hemorajik rüptüre kitle nedeni ile sütür ile hemostaz ve packing ile ilk müdahalesi yapılan hasta daha sonra tarafımızca genel durumu ve vital bulguları düzeltilerek tekrar operasyona alınmış depacking sonrası karaciğer segment $4 \mathrm{~b}$ rezeksiyonu ve kolesistektomi operasyonu yapılmıştır. Hastanın postoperatif dönemde patoloji sonucu iyi differansiye hepatosellüler karsinom olarak gelmiş olup bu olguda olduğu gibi yeterli tıbbi ve teknik ekipman olmadığında ilk cerrahi müdahale (sütürasyon ile hemostaz ve packing) sonrası ileri bir merkezde elektif cerrahi tedavi yaklaşımı da hayat kurtarıcı olabilir.

Anahtar sözcükler: Hepatosellüler karsinoma, spontan rüptür, tedavi

\begin{abstract}
İntraperitoneal hemorajic rupture is a complication of hepatocellular carcinoma that can be mortal. Surgical management and arterial embolisation are the main therapy choices in selected cases. We presented a case of hepatocellular carcinoma with spontaneous rupture and intra-abdominal hemorrhage. A 70 years old male was admitted to emergency department with abdominal pain and unstable hemodynamy. Patient was taken the operation room due to intra-abdominal bleeding. Intraoperatif diagnosis was rupture haemorrhagic solid liver mass and they performed depacking and hemostasis. Then they decided to transport patient to our hospital (tertiary hospital). We perform depacking, liver segment resection (4b) and cholecystectomy operation. The histopathological examination for the resected specimen yielded the final diagnosis of welldifferentiated hepatocellular carcinoma. As in this case if there is not enough medical and technical equipment for curative surgery than after the first surgical intervention has been done transporting the patient to a tertiary hospital for curative surgery can be saving life.
\end{abstract}

Keywords: Hepatocellular carcinoma, spontaneous rupture, therapeutic

Geliş tarihi/Received: 11 Kasım 2013; Kabul tarihi/Accepted: 22 Eylül 2014

\section{*İletişim adresi:}

Dr. Volkan Öter, Gastroenteroloji Cerrahisi Kliniği, Türkiye Yüksek İhtisas Eğitim ve Araştırma Hastanesi, TR-06640 Ankara. E-posta: otervolkan@gmail.com 


\section{Giriş}

Hepatoselüler karsinoma (HSK) karaciğerin en sık görülen primer malign tümörüdür [1]. HSK; Uzakdoğu Asya, Afrika kıtasının güney bölümleri gibi viral hepatit insidansı yüksek toplumlarda daha fazla görülen, yaklaşık \%80'i kronik hepatit B ve kronik hepatit $\mathrm{C}$ enfeksiyonu zemininde gelişen primer malign karaciğer tümörüdür [1]. Ölüme sebep olan en sık üçüncü malign tümör olmakla beraber, dünyada en s1k görülen beşinci kanserdir. Her y1l yaklaşık olarak 500,000 yeni vaka tespit edilmekte ve her y1l 250,0001,000,000 insan HSK sonucu yaşamını yitirmektedir [2-3]. HSK rüptürüne bağlı gelişen intraperitoneal kanama yaşamı tehdit eden komplikasyonlardan birisidir ve HSK'l 1 hastaların \%3-15'inde tümör rüptürü geliştiği bildirilmektedir [4]. Rüptür olan olgularda akut dönemde ölüm oranı \%25-75 olarak bildirilmektedir [5]. Rüptüre olgularda tedavi seçenekleri; acil cerrahi müdahale (sütür ile hemostaz sağlanması, rezeksiyon) veya anjiografi ile transarteryal embolizasyon ve daha sonrasında rezeksiyon şeklinde olabilir [6]. Bu yazıda HSK rüptürüne bağlı gelişen intraperitoneal kanama nedeniyle opere edilen olguyu sunmayı amaçladık.

\section{Olgu sunumu}

Daha önceden bilinen hastalığı olmayan 70 yaşında erkek hasta, ani başlangıçlı, çok şiddetli, sırta yayılır tarzda sürekli devam eden künt karın ağrısı ve baş dönmesi nedeniyle diş merkezde acil servise başvurmuş. Dış merkezde yapılan kan tetkiklerinde hemoglobin değeri $8,5 \mathrm{~g} / \mathrm{dL}$ saptanmış. Fizik muayenesinde karında distansiyon ve sağ üst kadranda hassasiyet saptanan hastaya abdominopelvik bilgisayarlı tomografi (BT) çekilmiş. BT'de karın iç yaygın sıvı (hemoraji?) ve kc segment $4 \mathrm{~b}$ 'de ekzofitik kitle ile bu kitlenin etrafında serbest sıvı saptanması üzerine (Şekil 1,2) hasta acil ameliyata alınmış ve laparotomide karın içinde hemoraji ve karaciğer segment $4 \mathrm{~b}$ 'de ekzofitik uzanımlı 6x3 cm aktif kanamalı kitle gözlenmiştir. Öncelikle hemostaz amaçlı karaciğere primer sütürasyon yapılmış ancak kanamanın devam etmesi üzerine karaciğere packing yapılarak karın içine dren yerleştirilip karın kapatılmışıı. Peroperatif ve postoperatif dönemde 3 ünite eritrosit süspansiyonu verilmesine rağmen karın drenlerinden hemorajik özellikte gelenin devam etmesi ve hemogram değerinde düşme olması nedeniyle postoperatif birinci gün kliniğimize sevk edilmiş.

Hastanın acil servise geldiğinde yapılan fizik muayenesinde; genel durumu orta, şuuru açık, oryantasyon ve kooperasyonu tam, aksiller vücut 1sıs1 $36,7{ }^{\circ} \mathrm{C}$, arteryel tansiyon 90/60 mm/Hg, nabız 105/dak., cilt ve mukozalar soluk idi. Karın muayenesinde sağda 2 adet dren mevcuttu. Karın palpasyonda hassas idi ancak defans ve rebound yoktu. Sağ üstteki drenden yaklaşık 300 cc kadar hemorajik gelen mevcuttu. Laboratuar incelemelerinde; WBC: $3500 / \mathrm{mm}^{3}$, Hgb: $8,7 \mathrm{~g} / \mathrm{dL}$, Htc: \%25,4; PLT: $148,000 / \mathrm{mm}^{3}$, Glukoz: $115 \mathrm{mg} / \mathrm{dL}$, ALT: $180 \mathrm{U} / \mathrm{L}$, AST: 90U/L, GGT: 15U/L, ALP: 48 U/L, Albumin: 2,42 g/dL, T. Bilirubin: 1,1 g/dL, D. Bilirubin: 0,4 g/dL, BUN: $97 \mathrm{mg} / \mathrm{dL}$, Kreatinin: 1,62 g/dL, PT: 15,6 saniye, INR: 1,41; CRP: 376 (N: 0-8) olarak tespit edildi. HBsAg ve AntiHCV negatifti. Serum AFP değeri $2,11 \mathrm{IU} / \mathrm{mL}(\mathrm{N}: 0,41-7,43)$, CEA $0,78 \mathrm{ng} / \mathrm{mL}$ ve CA $19-9 ; 17,1 \mathrm{U} / \mathrm{mL}$ idi. Hipovolemik şokta olan hastaya intravenöz hidrasyon, 2 ünite taze donmuş plazma ve 2 ünite eritrosit süspansiyonu desteği sonrası hastanın hemoglobin değeri 10,6 g/dL ve tansiyon arteryel değeri 110/60 mmHg oldu. Hipovolemik şok tablosu düzelen ve dreninden aktif kanaması olmayan hasta genel durumu düzeltildikten sonra depacking için postop üçüncü gün ameliyat edildi. Eksplorasyonda karaciğer segment 4b'de ekzofitik uzanımlı, aktif hemorajisi olmayan etrafinda 3 adet kompres ile packing yapılmış, safra kesesinin sol lateraline de uzanım gösteren yaklaşık $6 \times 4$ cm'lik düzensiz konturlu sert nodüler kitle palpe edildi. İntraoperatif ultrasonografi yapılarak karaciğerin segmenter anatomisi ve tümörün intraparankimal uzanımı belirlendikten sonra karaciğer parankiminde temiz cerrahi sınır sağlanacak şekilde segment $4 \mathrm{~b}$ rezeksiyonu yapıldı. Kitlenin safra kesesine yakın komşuluğu nedeni ile kolesistektomi de yapıldı. Patoloji sonucu $5 \times 3 \mathrm{~cm}$ boyutlarında heptaosellüler karsinom (iyi differansiye) olarak raporlandı (Şekil 3). Cerrahi sınırlarda tümör saptanmadı. 
Kapsül ve vasküler invazyon yoktu. Postoperatif takiplerinde komplikasyon gelişmeyen hasta yedinci gün taburcu edildi.

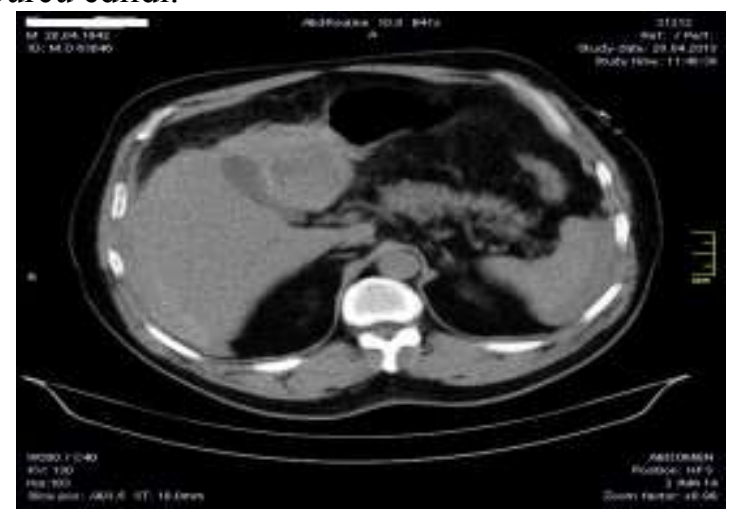

Şekil 1. BT'de karaciğer segment 4b'de rüptüre neden olan kitle.

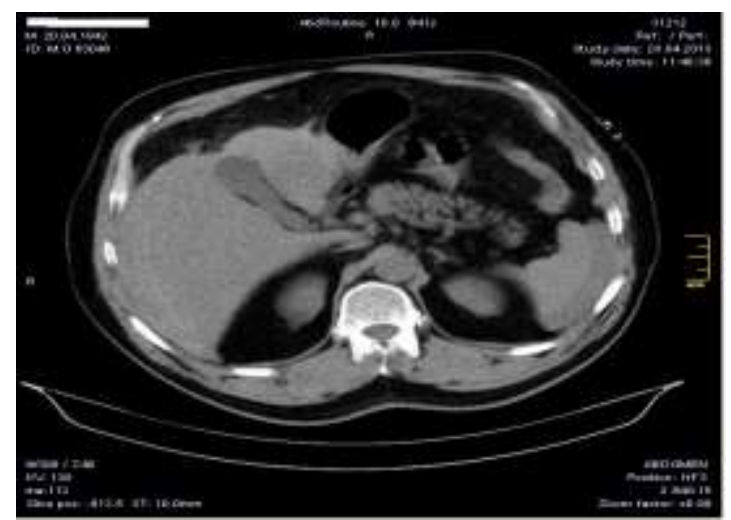

Şekil 2. BT'de karaciğerde kitle rüptürüne bağlı intraabdominal kanama.

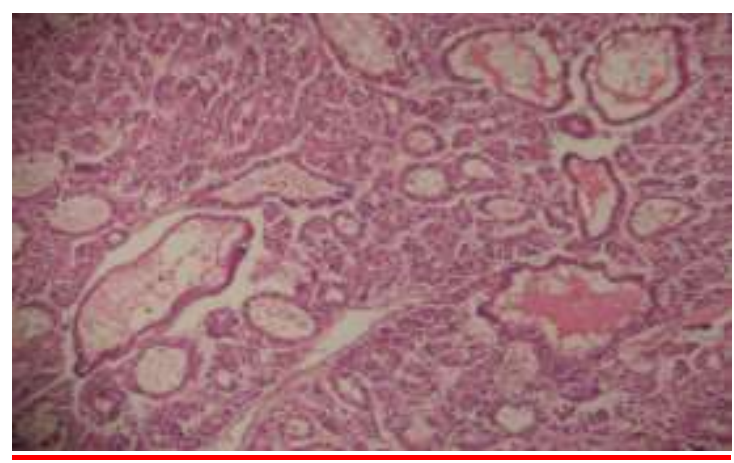

Şekil 3. İyi differansiye HCC patolojik görüntüsü (H\&E; x200).

\section{Tartışma}

Spontan intraperitoneal rüptür sonrası masif kanama HSK'nın ölümcül seyredebilen bir komplikasyonudur. Rüptür olan olgularda akut dönemde ölüm oranı \%25-75 olarak bildirilmektedir [5]. Spontan rüptüre olan olgularda en sık ortaya çıkan semptomlar: ani başlangıçlı karın ağrısı (\%58), başvuru anında şok bulgularının olması (\%46) ve abdominal distansiyon (\%42) olarak bildirilmiştir [6]. Hastamızda da ilk başvurusunda karın ağrısı, batın distansiyonu ve şok bulguları mevcuttu.

Hızlı tümör büyümesi nedeniyle oluşan santral nekroz, trombositopeni ve protrombin sentez bozukluğuyla ilişkili koagülopati, direkt tümör invazyonu nedeniyle ortaya çıkan 
venöz hipertansiyon, travma ve solunum hareketleriyle diafragmın yarattığı kompresyon literatürde spontan HSK rüptürü ile ilişkili olduğu düşünülen çeşitli mekanizmalar arasındadır [7, 8]. HSK rüptürü tanısını koymak özellikle öncesinde siroz veya HSK tanısı olmayan hastalarda zordur [9]. Hastaların anamnez ve fizik muayene bulguları ile rüptür şüphesi olduğunda ileri tetkik ihtiyacı vardır. Abdominal BT ile karaciğer içindeki vasküler tümör alanı ve tümör dansitesine yakın intraperitoneal sıvı birikimi gösterilebilir [10]. Bizim hastamızda da daha önceden HSK tanısı ve siroz bulguları yoktu. Hastanın dış merkezde çekilen Abdominal BT'sinde karaciğerde arteryel fazda kontrastlanan vasküler kitlesi olması ve etrafında intraperitoneal sıvı birikimi nedeni ile spontan rüptür düşünüldü. Spontan rüptür HSK'nın ölümcül bir komplikasyonudur, masif kanama hızlı müdahale edilemezse şok tablosu ile hayatı tehdit edecek boyutlara ulaşabilmektedir [11]. Yapılan bir çalışmada, HSK spontan rüptür olgularında 30 günlük mortalite oranının \%30-70 arasında değiştiği bildirilmektedir [12]. Erken dönemde mortaliteye etki eden faktörler yüksek Child-Pugh skoru, yüksek serum AST seviyesi, hepatik ensefolopatinin varlığ1, yüksek serum bilürübin seviyesi ve düşük serum albumin seviyesi olarak tespit edilmiş̧ir [13]. Hastamızın serum albumin değeri düşük ve serum AST değeri yüksek olup, Child Pugh sınıflamasına göre Child A idi. HSK rüptürlerinde girişim seçenekleri acil cerrahi müdahale (sütür ile hemostaz sağlanması veya rezeksiyon), transarteryal embolizasyon ve sonrası geciktirilmiş rezeksiyon şeklinde özetlenebilir [14]. Hastamızda kitlenin ekzofitik yerleşimli olması, drenlerden aktif kanama olmaması ve depacking için ameliyata alınması düşünüldüğünden ve kitlenin preoperatif değerlendirmede rezektabl olduğu düşünüldüğünden transarteryel embolizasyon uygulanmadı.

Sonuç olarak; acil olarak karşılaşılan kanamalı karaciğer kitlelerinde rüptür düşünüldüğünde deneyim ve ekipman yetersizliği varsa primer sütür ile hemostaz ve packing seçilecek tedavi yöntemi olmalıdır. Hasta daha iyi sonuçlar elde edilmesi için girişimsel radyoloji ve karaciğer cerrahisinin de bulunduğu deneyimli bir merkeze sevk edilmelidir.

\section{Kaynaklar}

1. Perz JF, Armstrong GL, Farrington LA. The contributions of hepatitis B virus and hepatitis $\mathrm{C}$ virus infections to cirrhosis and primary liver cancer worldwide. $\mathrm{J}$ Hepatol 2006; 45: 529-38.

2. Parkin DM, Bray F, Ferlay J, Pisani P. Estimating the world cancer burden: GLOBOCAN 2000. Int J Cancer 2001; 94: 153-6.

3. Llovet JM, Burroughs A, Bruix J. Hepatocellular carcinoma. Lancet 2003; 362: 1907-17.

4. Vergara V, Muratore A, Bouzari H. Spontaneous rupture of hepatocellular carcinoma: Surgical resection and long-term survival. Eur J Surg Oncol 2000; 26: 770-2.

5. Nouchi T, Nishimura M, Maeda $M$. Transcatheter arterial embolization of ruptured hepatocellular carcinoma associated with liver cirrhosis. Dig Dis Sci 1984; 29: 1137-41.

6. Hiroyuki Kirikoshi, Satoru Saito, Masato Yoneda. Outcomes and factors influencing survival in cirrhotic cases with spontaneous rupture of hepatocellular carcinoma: A multicenter study. BMC Gastroenterology 2009; 30: 29.

7. Zhu LX, Wang GS, Fan ST. Spontaneous rupture of hepatocellular carcinoma. Br J Surg 1996; 3: 602-7.

8. Zhu LX, Geng XP, Fan ST. Spontaneous rupture of hepatocellular carcinoma and vascular injury. Arch Surg 2001; 136: 682-7.

9. Vivarelli M, Cavallari A, Bellusci R. Ruptured hepatocellular carcinoma: An important cause of spontaneous haemoperitoneum in Italy. Eur J Surg 1995; 161: 881-6.

10. Pombo F, Arrojo L, Perez Fontan J. Hemoperitoneum secondary to spontaneous rupture of hepatocelluar carcinoma: CT diagnosis. Clin Radiol 1991; 43: 321-2. 
11. Polat KY, Akcay MN, Aydinlı B. Spontaneous rupture of hepatocelluler carcinoma: a case report and review of literature. Int J Clin Pract Suppl 2005; 103-5.

12. Tan FL, Tan YM, Chung AY. Factors affecting early mortality in spontaneous rupture of hepatocellular carsinoma. ANZ J Surg 2006, 76: 448-52.

13. Liu CL, Fan ST, Lo CM. Management of spontaneous rupture of hepatocellular carcinoma: Single-center experience. J Clin Oncol. 2001; 19: 3725-32.

14. Buczkowski AK, Kim PT, Ho SG. Multidisciplinary management of ruptured hepatocellular carcinoma. J Gastrointest Surg 2006; 10: 379-86. 